\title{
Zinc and curcumin lower arylsulfatses and some metabolic parameters in streptozotocin-induced diabetes
}

\author{
Mahmoud Balbaa ${ }^{*}$ (D), Marwa El-Zeftawy², Nabil Taha² and Abdel-Wahab Mandour ${ }^{2}$
}

\begin{abstract}
In rats with induced diabetes, Zinc and curcumin treatment showed a significant increase of catalase and a significant decrease of glucose, lipid profile components and arylsulphatases activity compared to the untreated rats. We suggest that dietary zinc and curcumin are promising protective agents for reducing the metabolic defect of diabetes.
\end{abstract}

\section{Dear Editor;}

Diabetes mellitus is a metabolic disease and the pathogenesis of diabetes mellitus is implicated in the oxidative stress and the generation of superoxide free radicals [1]. Various small molecules have been investigated for their ability to ameliorate the diabetes. One such molecule is curcumin (Cur) that has various health beneficial properties such as anti-inflammatory, anticarcinogenic, antiviral, hypolipidemic and antiinfectious activities [2,3]. The 2nd molecule is the zinc $(\mathrm{Zn})$ salt as an essential trace element. The disturbances of its homeostasis seem to be associated not only with diabetes, but also with others [4]. Recently, it was reported that the lysosomal enzymes arylsulfatases were significantly changed in experimental diabetes [5]. In fact, the treatment of diabetes through food sources is valuable around the world. Therefore, the present study is undertaken to throw the light on the effect of $\mathrm{Zn}$ and Cur on rats with experimental diabetes rats through studying the effect on some lipid components and arylsulfatases as important parameters, which are implicated in different biological functions.

Male albino rats (120-160 g Bwt) were kept on a balanced ration with water ad libitum for acclimatization. Experimental diabetes was induced in overnight fasted rats by intraperitoneal injection of a single dose of streptozotocin (STZ) as $60 \mathrm{mg} / \mathrm{kg}$ Bwt. Rats with a serum glucose level $218 \mathrm{mg} / \mathrm{dl}$ were considered as rats with diabetes. The daily intake of $\mathrm{Zn}$ sulfate $(100 \mathrm{mg} / \mathrm{kg}$ Bwt) and was

\footnotetext{
* Correspondence: mahmoud.balbaa@alexu.edu.eg

${ }^{1}$ Departments of Biochemistry, Faculty of Science, Alexandria University,

Moharram Bey, 21511 Alexandria, Egypt

Full list of author information is available at the end of the article
}

administrated orally in non-ionized water for 60 days. Cur was suspended in saline and administrated orally by a gavage $80 \mathrm{mg} / \mathrm{kg}$ Bwt Cur suspended daily in saline for 60 days. The rats were grouped randomly into eight equal groups as the non-diabetic (control group), the diabetic group, $\mathrm{Zn}$ non-diabetic group, $\mathrm{Zn}$ diabetic group, Cur non-diabetic group, Cur diabetic group. The last two groups that belong to $\mathrm{Zn}$ and $\mathrm{Cur}$ non-diabetic and diabetic group received 50 and $40 \mathrm{mg} / \mathrm{kg}$ Bwt, respectively as a daily for 60 days. The animals were deprived of food overnight and sacrificed by decapitation. Blood was collected from the eye canthus in tubes containing potassium oxalate and sodium fluoride mixture for estimation of plasma glucose (PG). Liver or pancreas tissues were weighed, homogenized in $10 \mathrm{mM}$ Tris $\mathrm{HCl}$ buffer, pH 7.0 and centrifuged at $4000 \mathrm{rpm}$ for $15 \mathrm{~min}$ at $4{ }^{\circ} \mathrm{C}$. The clear supernatant was obtained to measure the activities of catalase [6], total protein [7] and both arylsulfatase A (ASA) and arylsulfatase B (ASB) [8]. ASA and ASB were fractionated by DEAE-cellulose chromatography as described previously [8]. Insulin was assayed in the homogenate of pancreas of all groups according to instruction of Sigma-Aldrich insulin ELISA kit. Serum total cholesterol (STC) was determined by cholesterol oxidase and peroxidase [9]. Serum triacylglycerol (STG) was determined as described previously [10]. Serum LDL cholesterol (SLDL-c) and HDL cholesterol (SHDL-c) levels were estimated as that described previously [11]. The obtained data during the experimental period were statistically analyzed by the paired sample T-test (SPSS version 16). 
Table 1 Effect of Zn and curcumin on Lipid Profile distribution

\begin{tabular}{|c|c|c|c|c|c|}
\hline Groups & $\begin{array}{l}\text { Plasma glucose } \\
(\mathrm{PG}, \mathrm{mg} / \mathrm{dl})\end{array}$ & Serum total cholesterol & Serum triacylglycerol & Serum LDL & Serum HDL \\
\hline Control & $111.84 \pm 2.56$ & $50.25 \pm 1.54$ & $37.2 \pm 1.73$ & $63.75 \pm 3.20$ & $106.56 \pm 3.04$ \\
\hline Diabetic & $381.81 \pm 15.12^{* *}$ & $137.02 \pm 7.04^{* *}$ & $635.63 \pm 29.57^{* *}$ & $50.71 \pm 6.22^{* *}$ & $41.79 \pm 1.38^{* *}$ \\
\hline Zn non-diabetic & $73.61 \pm 2.21^{*}$ & $32.67 \pm 1.31^{*}$ & $37.9 \pm 1.01$ & $72.16 \pm 3.40$ & $79.24 \pm 2.83^{*}$ \\
\hline Zn-treated diabetic & $138.59 \pm 7.81^{*}$ & $60.34 \pm 3.67^{*}$ & $116.40 \pm 3.54^{*}$ & $61.98 \pm 4.44$ & $99.04 \pm 3.19$ \\
\hline Cur non-diabetic & $74.47 \pm 2.99^{*}$ & $47.49 \pm 1.45$ & $23.95 \pm 0.86^{*}$ & $56.70 \pm 2.24$ & $99.99 \pm 2.19$ \\
\hline Cur-treated diabetic & $124.88 \pm 4.36^{*}$ & $59.13 \pm 3.07^{*}$ & $30.95 \pm 1.39^{*}$ & $28.51 \pm 3.60^{*}$ & $82.61 \pm 3.40^{*}$ \\
\hline Zn and Cur non-diabetic & $111.08 \pm 4.39$ & $47.15 \pm 1.60$ & $34.53 \pm 1.66$ & $58.09 \pm 3.01$ & $98.33 \pm 2.40$ \\
\hline Zn and Cur- treated diabetic & $118.22 \pm 4.90$ & $51.47 \pm 1.37$ & $41.3 \pm 2.30$ & $38.88 \pm 2.56^{*}$ & $82.89 \pm 2.50^{*}$ \\
\hline
\end{tabular}

The mean values of the serum level (mg/dl) of total cholesterol, triacylglycerol and the lipoproteins LDL and HDL in control, diabetic, Zn- and curcumin-treated diabetic groups. The values are the means of 12 rats \pm SE. Significance: ${ }^{*} p<0.05$ and ${ }^{* *} p<0.001$ compared to control

A significant increase of plasma glucose was noted after one and 60 days of STZ injection. Oral administration of $\mathrm{Zn}$, Cur and a combination of both showed a significant effect on blood glucose levels (1.9 fold-increase). Similar results were obtained by the effect of Cur, whereas an increase of plasma sugar level of 4.7 folds in day one was changed to be only 1.7 fold after 60 days of STZ-treatment. Interestingly, on treating the rats by both $\mathrm{Zn}$ and Cur, the noticed significant change of plasma sugar level in day one was changed to be non-significant at 60 days of STZtreatment (Table 1). A reversed tendency to that of plasma glucose was shown on measuring the insulin content of pancreatic homogenate of animals from the different groups. The rats with diabetes showed a significant decrease ( 4.4 fold) in insulin compared to control $(p<$ 0.001). Insulin level showed a non-significant change after treatment with $\mathrm{Zn}$ and Cur. In addition, a significant increase in the levels of serum total cholesterol (STC) and triacylglycerol (STG) in the diabetic groups was noticed in comparison to the non-diabetic groups. Comparison of the diabetic groups versus the non-diabetic groups showed a significant decrease in both SHDL-c and SLDL-c levels in the diabetic groups and a significant increase after treatment with $\mathrm{Zn}$ and Cur (Table 1). For studying the effect of $\mathrm{Zn}$ and Cur on free radical production, the activity of catalase was measured in both plasma and liver. It presented a significant decrease in diabetic compared to control rats. The effect of $\mathrm{Zn}$ and Cur showed a significant increase of the specific activity in serum and hepatic catalase compared to STZinduced diabetic rats $(p<0.05)$. Furthermore, there is a significant increase in the specific activities of ASA and ASB in both serum and liver in the rats of the diabetic group compared to control (Table 2). $\mathrm{Zn}$ and Cur administration decrease it significantly compared to the diabetic group $(p<0.05)$. The significant increase of catalase by $\mathrm{Zn}$ may be attributed to the competition of $\mathrm{Zn}$ to both iron and copper for binding to cell membranes and thus decreasing the production of $\mathrm{OH}^{-}$group [12]. This group in turn stimulates the peroxidation of membrane lipids and hence the outflow of lysosomal constituents into cytosol [13]. The role of combination of both $\mathrm{Zn}$ and Cur in diabetes showed a highly significant effective result than the use of $\mathrm{Zn}$ or Cur alone. Taken together, we suggest that $\mathrm{Zn}$ and Cur have an effective and a protective role against the effect of diabetes-produced radicals on lysosomes. Dietary $\mathrm{Zn}$ and Cur are promising protective agents with a potential therapeutic approach to diabetes.

Table 2 Effect of Zn and Cur on the specific activity of catalase (units/mg protein) and arylsulfatases ASA and ASB (nmol product/h/mg protein)

\begin{tabular}{lllllll}
\hline Groups & Serum Catalase $\left(\times 10^{4}\right)$ & Hepatic Catalase $\left(\times 10^{4}\right)$ & Serum ASA & Hepatic ASA & Serum ASB & Hepatic ASB \\
\hline Control & $1.09 \pm 0.05$ & $28.5 \pm 1.4$ & $12.01 \pm 0.74$ & $226.78 \pm 10.25$ & $23.28 \pm 1.50$ & $505.82 \pm 23.03$ \\
Diabetic & $0.49 \pm 0.03^{* *}$ & $4.4 \pm 0.4^{* *}$ & $25.58 \pm 0.89^{* *}$ & $555.36 \pm 52.49^{* *}$ & $34.24 \pm 1.90^{*}$ & $627.79 \pm 53.18^{* *}$ \\
Zn non-diabetic & $1.00 \pm 0.03$ & $36.4 \pm 2.8^{*}$ & $15.25 \pm 0.81$ & $268.04 \pm 6.78^{*}$ & $34.69 \pm 1.62^{*}$ & $531.61 \pm 17.67^{*}$ \\
Zn-treated diabetic & $0.97 \pm 0.03$ & $34.1 \pm 1.5^{*}$ & $9.53 \pm 0.78^{*}$ & $214.66 \pm 3.99^{*}$ & $21.42 \pm 1.02$ & $408.94 \pm 15.37^{*}$ \\
Cur non-diabetic & $0.88 \pm 0.03$ & $36.9 \pm 2.0^{*}$ & $14.86 \pm 0.51$ & $261.32 \pm 8.47^{*}$ & $33.26 \pm 2.08^{*}$ & $604.90 \pm 11.17^{*}$ \\
Cur-treated diabetic & $1.03 \pm 0.03$ & $47.1 \pm 1.9^{*}$ & $11.13 \pm 0.66$ & $260.33 \pm 10.70^{*}$ & $32.87 \pm 1.96^{*}$ & $431.83 \pm 22.81^{*}$ \\
Zn and Cur non-diabetic & $1.01 \pm 0.03$ & $35.8 \pm 1.5^{*}$ & $12.46 \pm 0.23$ & $174.60 \pm 10.17^{*}$ & $31.10 \pm 1.11^{*}$ & $501.37 \pm 17.75$ \\
Zn and Cur-treated diabetic & $1.00 \pm 0.02$ & $36.2 \pm 2.5^{*}$ & $9.32 \pm 0.40^{*}$ & $150.59 \pm 11.39^{*}$ & $20.28 \pm 1.14$ & $333.67 \pm 22.74^{*}$ \\
\hline
\end{tabular}

The values are the means of 12 rats \pm SE. Significance: ${ }^{*} p<0.05$ and ${ }^{* *} p<0.001$ compared to control 


\section{Abbreviations}

ASA: Arylsulfatase A; ASB: Arylsulfatase B; Bwt: Body weight; Cur: Curcumin; PG: Plasma glucose; SHDL-C: Serum high density lipoprotein cholesterol; SLDL-c: Serum low density lipoprotein cholesterol; STC: Serum total cholesterol; STG: Serum total triacylglycerol; STZ: Streptozotocin

\section{Acknowledgements}

The authors thank the technical staff of Department of Biochemistry, Faculty of Science, Alexandria University, Egypt for their helpful assistance.

\section{Funding}

This letter was extracted from an ongoing research project that is conducted by Mahmoud Balbaa and coworkers. This project was partially supported by Alexandria University, Egypt.

\section{Availability of data and materials}

Data sharing is not applicable to this article as no datasets were generated or analyzed during the current study.

\section{Authors' contributions}

MB participated in acquisition of the data, study concept and design, data interpretation, data analysis and critical revision of the manuscript for important intellectual content. ME participated in acquisition of the data, study concept and design, analysis and interpretation of the data, drafting of the manuscript and critical revision of the manuscript for important intellectual content. NT participated in the interpretation of the data and drafting of the manuscript. AM participated in the interpretation of the data. All authors read and approved the final manuscript.

\section{Competing interests}

The authors declare that they have no competing interests.

\section{Consent for publication}

This article is original and was not published in any other journal. We have declared to give a right to publish in Journal of Diabetes \& Metabolic Disorders.

\section{Ethics approval and consent to participate}

All the experimental procedures were conducted according to the animal protocols approved by the Ethics Committee of Faculty of Science, Alexandria University, Egypt.

\section{Publisher's Note}

Springer Nature remains neutral with regard to jurisdictional claims in published maps and institutional affiliations.

\section{Author details}

${ }^{1}$ Departments of Biochemistry, Faculty of Science, Alexandria University, Moharram Bey, 21511 Alexandria, Egypt. ²Edfina Faculty of Veterinary Medicine, Alexandria University, Alexandria, Egypt.

Received: 12 October 2016 Accepted: 6 March 2017

Published online: 14 March 2017

\section{References}

1. Firoozrai M, Nourbakhsh M, Razzaghy-Azar M. Erythrocyte susceptibility to oxidative stress and antioxidant status in patients with type 1 diabetes. Diabetes Res Clin Pract. 2007;77:427-32.

2. Joe B, Vijaykumar M, Lokesh BR. Biolgical properties of curcumin-cellular and molecular mechanisms of action. Crit Rev Food Sci Nutr. 2009:44:97-111.

3. Best L, Elliott AC, Brown PD. Curcumin induces electrical activity in rat pancreatic beta-cells by activating the volume-regulated anion channel. Biochem Pharmacol. 2007;73:1768-75.

4. Jansen J, Karges W, Rink L. Zinc and diabetes- clinical links and molecular mechanisms. J Nutr Biochem. 2009:20:399-417.

5. Samarji R, Balbaa M. Anti-diabetic activity of different oils through their effect on arylsulfatases. J Diabetes Metab Disord. 2014:13:116. doi:10.1186/s40200-014-0116-z.

6. Aebi H. Catalase in vitro. Methods Enzymol. 1984;105:121-26.

7. Doumas BT, Bayse DD, Carter R, Peters Jr T, Schaffer R. A candidate reference method for determination of total protein in serum. I. Development and validation. Clin Chem. 1981;27:1642-50.
8. Balbaa M, El-Kersh M, Mansour H, Yacout G, Ismail M, Malky A, Bassiouny K, Abdel-Monem N, Kandeel K. Activity of some hepatic enzymes in schistosomiasis and concomitant alteration of arylsulfatase B. J Biochem Mol Biol. 2004;37:223-28.

9. Flegg HM. Cholesterol reagent. Ann Clin Biochem. 1973;10:79-84.

10. Bucolo G, David H. Quantitative determination of serum triglycerides by the use of enzymes. Clin Chem. 1973;19:476-82.

11. Burestein M, Scholnick HR, Morfin R. Rapid method for the isolation of lipoproteins from human serum by precipitation with polyanions. J Lipid Res. 1970;11:583-93.

12. Prasad AS. Clinical, immunological, anti-inflammatory and anti-oxidant roles of zinc. Exp Gerontol. 2008:43:370-77.

13. Boya P, Kroemer G. Lysosomal membrane permeabilization in cell death. Oncogene. 2008:27:6434-51

\section{Submit your next manuscript to BioMed Central and we will help you at every step:}

- We accept pre-submission inquiries

- Our selector tool helps you to find the most relevant journal

- We provide round the clock customer support

- Convenient online submission

- Thorough peer review

- Inclusion in PubMed and all major indexing services

- Maximum visibility for your research

Submit your manuscript at www.biomedcentral.com/submit
Biomed Central 